\title{
Monogenic diabetes mellitus in Norway
}

\author{
Oddmund Søvik $^{\mathrm{a}, \mathrm{b}}$,Henrik Underthun Irgens ${ }^{\mathrm{a}, \mathrm{b}, \mathrm{c}}$, Janne Molnes ${ }^{\mathrm{a}, \mathrm{b}}$, Jørn V. Sagen ${ }^{\mathrm{a}, \mathrm{d}, \mathrm{e}}$, \\ Lise Bjørkhaug ${ }^{\mathrm{a}, \mathrm{b}, \mathrm{f}}$, Helge Ræder ${ }^{\mathrm{a}, \mathrm{b}, \mathrm{c}}$, Anders Molven ${ }^{\mathrm{g}, \mathrm{h}}$ and Pål R. Njølstad ${ }^{\mathrm{a}, \mathrm{b}, \mathrm{c},{ }^{*}, \S}$ \\ ${ }^{a} K G$ Jebsen Center for Diabetes Research, University of Bergen, Bergen \\ ${ }^{b}$ Department of Clinical Medicine, University of Bergen, Bergen \\ ${ }^{c}$ Department of Pediatrics, Haukeland University Hospital, Bergen \\ ${ }^{d}$ Hormone Laboratory, Haukeland University Hospital, Bergen \\ ${ }^{e}$ Institute of Medicine, University of Bergen, Bergen \\ ${ }^{f}$ Center for Medical Genetics and Molecular Medicine, Haukeland University Hospital, Bergen \\ ${ }^{g}$ The Gade Institute, University of Bergen, Bergen \\ ${ }^{h}$ Department of Pathology, Haukeland University Hospital, Bergen, Norway \\ *Correspondence: Pål Rasmus Njølstad, Department of Pediatrics, Haukeland University Hospital, N-5021 Bergen, Norway \\ E-mail: pal.njolstad@uib.no \\ §Present address: Pål Rasmus Njølstad, Broad Institute, 7 Cambridge Center, \#5028C, Cambridge, MA 02142, USA
}

\begin{abstract}
Here, we review data on monogenic diabetes mellitus in Norway based on the Norwegian MODY Registry at Haukeland University Hospital, Bergen. This registry comprises established or suspected cases of maturity-onset diabetes of the young (MODY) referred to our laboratory for genetic testing. We also present data on neonatal diabetes, another group of monogenic diabetes. To date, we have genetically diagnosed nearly 500 MODY cases in Norway. Mutations in the HNF1A gene (MODY3) were detected in about $50 \%$ of families with clinical MODY. GCK-MODY (MODY2) was the second most prevalent type, but may be underreported. We have also found mutations in the monogenic genes $A B C C 8, C E L, H N F 1 B$, HNF4A, INS, KCNJ11 and NEUROD1. Based on genetic screening in the Norwegian MODY Registry and HUNT2, we estimate the number of MODY cases in Norway to be at least 2500-5000. Founder effects may determine the geographical distribution of MODY mutations in Norway. The molecular genetic testing of MODY and neonatal diabetes is mandatory for correct diagnosis and prognosis as well as choice of therapy.
\end{abstract}

\section{INTRODUCTION}

Whereas type 1 and type 2 diabetes are caused by a combination of several genetic and environmental factors, monogenic diabetes is caused by defect in a single gene only. The two main types of monogenic diabetes are maturity-onset diabetes of the young (MODY) and neonatal diabetes mellitus (1). In both types, a molecular genetic classification is necessary to choose the best possible treatment, and also for adequate prognosis prediction. In Norway, genetic testing of monogenic diabetes is performed at the Center for Diabetes Genetics and Center for Medical Genetics and Molecular Medicine at Haukeland University Hospital in Bergen. Patients can be referred for clinical investigations and genetic counseling as well as genetic testing. Necessary forms and addresses are available at the web site www.mody.no.

The purpose of the present article is to provide an update on monogenic diabetes in Norway, focusing on classification, prevalence and phenotypic expression. It should be noted that in patients with suspected monogenic diabetes mellitus, the results of pancreatic imaging could help to guide the molecular and genetic investigation (2). The results presented are mainly from the Norwegian MODY Registry (see below). Data were also obtained from the HUNT2 Study and from the Norwegian Childhood Diabetes Registry.
Studies on monogenic diabetes in Norway date back to the late 1960ies (3), whereas MODY type diabetes was first recognized in a family on the north-west coast of the country (4). In this "type 2-like diabetes" family, which we later designated the N1 family (Figure 1) and classified as HNF1A-MODY (5), clinical features of affected members were severe diabetic eye disease and increased sensitivity to sulfonylurea (6).

\section{THE NORWEGIAN MODY REGISTRY}

The Norwegian MODY Registry was established in 1997 as a nation-wide registry of patients with monogenic diabetes, for diagnostic and research purposes. A patient referral to the registry should fulfill at least two of the following criteria: 1) first degree relative with diabetes, 2) onset of diabetes before age 25 years in at least one family member, 3 ) low-dose of insulin requirement, 4) early-onset type 2 diabetes, i.e. diagnosed between age 25 and 40 years, and 5) unusual type 1like diabetes (low-dose insulin requirement, no antibodies, or atypical history).

Data have also been received from the HUNT2 study (1995-1997), in which 66140 persons from the county of Nord-Trøndelag participated, i.e. $71 \%$ of the eligible population (7). Furthermore, we have obtained some data from the Norwegian Childhood Diabetes Registry, which operates closely with the Norwegian Study Group of Childhood Diabetes. 


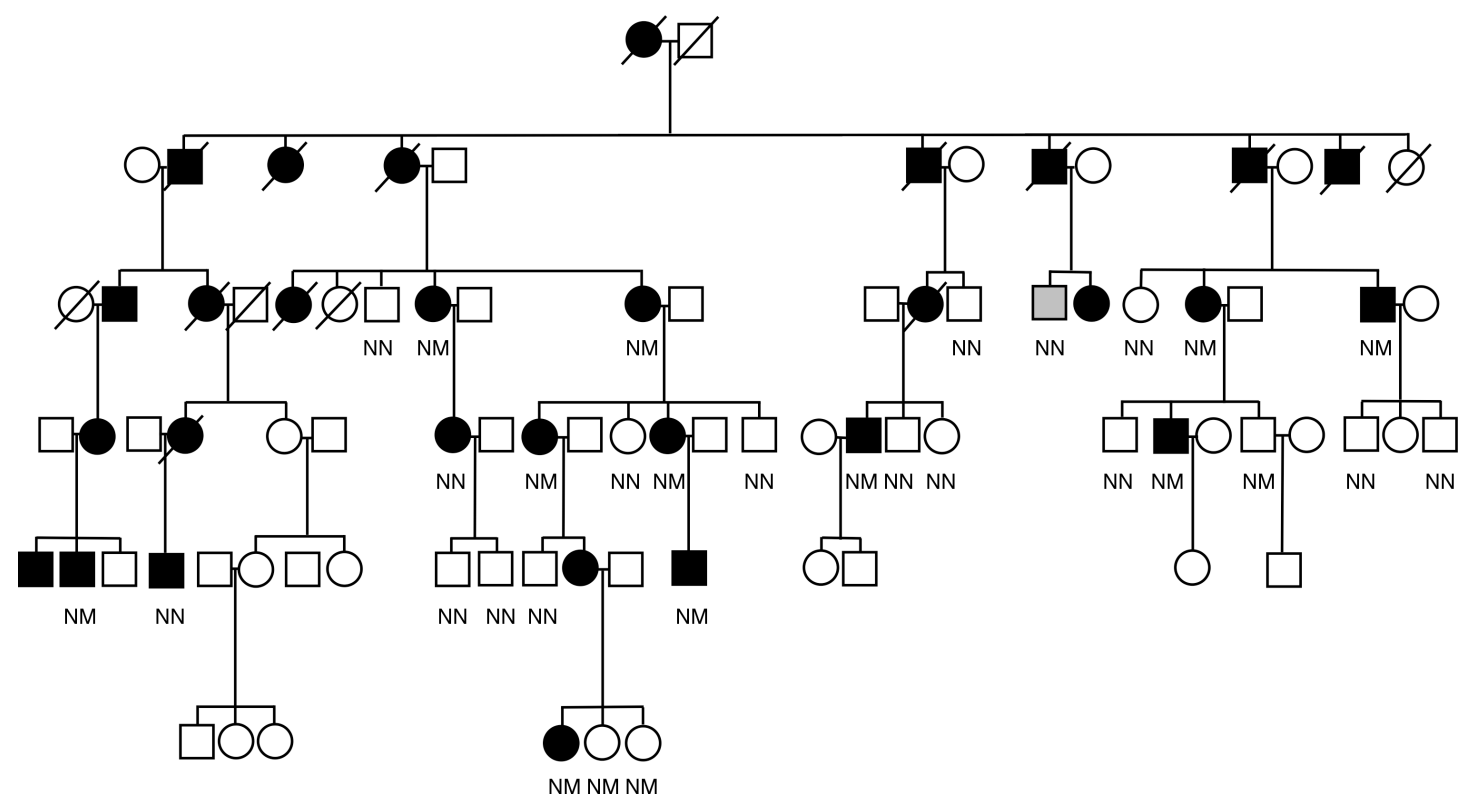

Figure 1. A large Norwegian family (N1) with an autosomal, dominant mutation of HNF1A. The figure illustrates that careful investigation of a family enriched for subjects with diabetes can reveal a pattern compatible with autosomal dominant diabetes. The subjects were in general lean and had an age of diagnosis most often less than 20-30 years. Thus, the family had MODY. Screening relevant MODY genes, the mutation P291fsinsC in the HNF1A gene was found and the diagnosis HNF1-MODY could be set. Normal glucose tolerance (white symbols), impaired glucose tolerance (gray symbols), diabetes mellitus (black symbols), mutation carrier with normal glucose tolerance (white icon with a dot). Mutation Status: NN, no mutation, NM, heterozygous mutation.

\section{MODY}

The Norwegian MODY Registry serves scientific and diagnostic purposes. Available data also shed light on classification and epidemiological parameters, in particular prevalence. As of September 1st 2012, around 1500 subjects were registered of which 458 patients from 198 MODY families had a genetic diagnosis (Table 1). The distribution of the most common MODY forms was as follows: HNF1A-MODY 53\%, GCKMODY $30 \%$, HNF4A-MODY $7.5 \%$, and HNF1BMODY 5.6\%. Families with $C E L$ and insulin gene mutations occur sporadically. Mutations in NEURODI were not found by routine diagnostic screening of Norwegian non-classified (MODYX) patients (8), although we have identified four cases from two families by whole-exome sequencing (Table 1).

To estimate the prevalence of HNF1A-MODY in Norwegian pedigrees with diabetes, Bjørkhaug et al. (5) screened 130 families for mutations in HNFIA. Mutations were found in 22 of 42 families with clinical MODY, 15 of 75 families with suspected MODY, and in one of 13 families with multiplex type 1-like diabetes. Thus, mutations in HNF1A were detected in about $50 \%$ of families with clinical MODY, in agreement with present updated numbers (Table 1 ).

Sagen et al. (9) screened for GCK mutations in 122 probands referred to the MODY Registry. Two novel and 13 previously reported mutations were found in 23 probands and in 33 of their family members. From this study, we concluded that GCK-MODY is less prevalent than HNF-1A-MODY.
Table 1. Genetically verified MODY cases and families in the Norwegian MODY Registry.

\begin{tabular}{lcc}
\hline & \multicolumn{2}{c}{ Number } \\
\cline { 2 - 3 } MODY subtype & Cases & Families \\
\hline HNF1A-MODY & 208 & 105 \\
GCK-MODY & 139 & 59 \\
HNF4A-MODY & 40 & 15 \\
HNF1B-MODY & 19 & 11 \\
CEL-MODY & 39 & 2 \\
INS-MODY & 9 & 4 \\
NEUROD1-MODY & 4 & 2 \\
Sum & $\mathbf{4 5 8}$ & $\mathbf{1 9 8}$ \\
\hline
\end{tabular}

Ræder et al. (10), sequencing the $H N F 4 A$ gene of 95 MODY3-negative probands from the MODY Registry, identified three novel $H N F 4 A$ mutations and a 3.7-MB haplotype, which was linked with diabetes. Of particular interest was the finding of two unrelated families with several subjects with the P2 promoter haplotype who were originally perceived as late-onset lean diabetes patients with a mean age of onset at 45 years. In conclusion, $H N F 4 A$ variants were considered to cause diabetes in $9 \%$ of $H N F 1 A$-negative probands.

So far, we have identified $H N F 1 B$ mutations in 19 cases from 11 families (Table 1). These patients typically present with progressive renal dysfunction and renal cysts prior to the development of diabetes (11-13).

Ræder et al. (14) identified $C E L$ mutations to be a novel cause of MODY, which later was denoted MODY8. Subsequent screening of 38 MODY patients negative for mutations in the common MODY genes 
identified another CEL-MODY family. These patients have both diabetes and pancreatic exocrine dysfunction with diabetes onset usually around the age of 35 years. CEL-MODY seems to be extremely rare (15).

Molven et al. (16) searched for INS mutations in 62 patients with MODY and 30 patients with suspected MODY from the MODY Registry, and identified the INS mutation c.137G $>$ A (R46Q) in one proband, his father, and a paternal aunt. They were diagnosed with diabetes at 20,18 and 17 years of age, respectively, and treated with small doses of insulin or diet only. In 223 type 1 diabetic patients from the Norwegian Childhood Diabetes Registry, selected on the basis of autoantibody negativity or family history of diabetes, the INS mutation c.163C $>\mathrm{T}$ (R55C) was found in a girl who had presented with ketoacidosis and antibody-negative diabetes at 10 years of age. INS mutations have been established as the third most common cause of neonatal diabetes (17). Our study suggests that INS screening should be considered also in MODY and in selected cases of type 1 diabetes.

By studying 1972 diabetic subjects from the HUNT2 Study, Eide et al. (18) identified a subgroup of 43 suspected MODY cases, based on clinical and laboratory findings. Thus, in the HUNT2 cohort, $2.2 \%$ of all subjects with self-reported diabetes could be classified as suspected MODY cases by clinical criteria. Within this group, $H N F 1 A$ mutations were found in three subjects, two with an R229Q mutation and one subject with a novel S6N alteration. Genotyping the total cohort of diabetic HUNT2 subjects revealed five additional R229Q-positive subjects. The minimum prevalence of HNF 1A MODY in Nord-Trøndelag could therefore be estimated to $0.4 \%$ of subjects with a diabetes diagnosis.

\section{NeONATAL DIABETES}

We have obtained a genetic diagnosis in 27 patients with neonatal diabetes (Table 2). The first patient molecularly characterized by us was a child with a homozygous $G C K$ mutation (19). We have not identified additional cases with neonatal diabetes and $G C K$ mutations in Norway, and homozygous or compound heterozygous $G C K$ mutations seem to be most frequent in regions where co-sanguinity is common (20). Chromosome 6 abnormalities (21) along with mutations in

Table 2. Genetically verified neonatal diabetes mellitus cases and families in the Norwegian MODY Registry.

\begin{tabular}{lcc}
\hline & \multicolumn{2}{c}{ Number } \\
\cline { 2 - 3 } Subtype & Cases & Families \\
\hline KCNJ11-PNDM & 15 & 14 \\
ABCC8-PNDM & 3 & 3 \\
Chromosome 6 abnormality & 7 & 7 \\
Wolcott-Rallison syndrome & 1 & 1 \\
Homozygous glucokinase deficiency & 1 & 1 \\
Sum & $\mathbf{2 7}$ & $\mathbf{2 6}$ \\
\hline
\end{tabular}

KCNJ11 and $A B C C 8$ are most numerous in Norway. Sagen et al. (22) sequenced the KCNJ11 gene encoding the Kir6.2 subunit of the potassium channel of the ß-cell, in 11 probands with permanent neonatal diabetes mellitus. There were nine mutation carriers in seven families from Norway, Israel, Turkey and the USA. In one Norwegian patient, glibenclamide was introduced in increasing doses. With a dose of $0.4 \mathrm{mg}$ per $\mathrm{kg}$ per day, insulin could be discontinued. This was the first case in the world where, based on a genetic diagnosis, a neonatal diabetes patient could have her insulin injections substituted with oral medication (22). It was later concluded that patients with mutations in KCNJ11 may be managed on oral sulfonylurea, even with sustained or improved metabolic control (23). This is now state-of-the-art treatment, not only in neonatal diabetes due to mutations in $K C N J 11$, but also in patients harboring mutations in the $A B C C 8$ gene (24).

\section{DisCUSSION}

The molecular diagnosis of monogenic diabetes has important implications for therapy, prognosis and genetic counseling. Thus, GCK-MODY may be treated by diet alone for years or permanently without insulin. Diabetic late complications are almost non-existent in this disease. HNF1A-MODY, on the other hand, is a potentially severe type of diabetes, well illustrated in the N1 family (Figure 1). HNF1A-MODY and HNF4AMODY cannot be distinguished by clinical criteria (Table 3). Subjects with these MODY forms have a progressive beta-cell failure. They are sulfonylureasensitive but many patients require insulin in the second to third decade of life. Due to this fact, HNF1A-MODY and HNF4A-MODY are frequently misdiagnosed as type 1 diabetes. It is important, however, to diagnose these MODY forms since sulfonylurea may be the drug of choice. Moreover, their offspring have a $50 \%$ chance for having diabetes as opposed to the $5 \%$ risk in type 1 diabetes.

The prevalence of MODY in Norway cannot be formally calculated from available data, but it is possible to make some estimates. With 458 registered cases of MODY from a population of about 5 million, a minimum prevalence in Norway would be 92 cases per million individuals. This is very close to the minimum prevalence of 108 cases per million in UK, registered by Shields and coworkers (25). An obvious question for Norway as well as UK, is how many cases are we missing in our registries? On the basis of a marked regional variation in the prevalence of confirmed MODY, two UK studies estimated that in the UK, 80$90 \%$ are not diagnosed by molecular testing $(25,26)$. If such a calculation were applied to Norway, we would arrive at a nation-wide number of 2500-5000 MODY cases.

We can also approach the question of prevalence from another point of view. In the HUNT2-material, clinical MODY criteria were fulfilled in $2.2 \%$ of dia- 
Table 3. Clinical characteristics of MODY types in the Norwegian MODY Registry.

\begin{tabular}{|c|c|c|c|c|}
\hline Gene/Name & Previous name & OMIM* No & Clinical characteristics & Diabetes treatment \\
\hline HNF4A-MODY & MODY1 & 125850 & $\begin{array}{l}\text { Similar to HNF1A-MODY, liver } \\
\text { enzymes may be increased }\end{array}$ & Sulfonylurea, insulin \\
\hline GCK-MODY & MODY2 & 125851 & $\begin{array}{l}\text { Slightly elevated blood glucose, stable } \\
\text { through life, no late complications }\end{array}$ & $\begin{array}{l}\text { None, but insulin } \\
\text { needed in pregnancy }\end{array}$ \\
\hline HNF1A-MODY & MODY3 & 600496 & $\begin{array}{l}\text { Progressive beta-cell dysfunction, late } \\
\text { complications as in type } 1 \text { diabetes }\end{array}$ & Sulfonylurea, insulin \\
\hline HNF1B-MODY & MODY5 & 137920 & $\begin{array}{l}\text { Malformations of kidneys, genitalia, } \\
\text { pancreas, progressive renal dysfunction }\end{array}$ & Insulin \\
\hline NEUROD1-MODY & MODY6 & 606394 & Mild diabetes, often obesity & $\begin{array}{l}\text { Oral hypoglycemic } \\
\text { agents, insulin }\end{array}$ \\
\hline CEL-MODY & MODY8 & 609812 & $\begin{array}{l}\text { Progressive of beta-cell dysfunction, } \\
\text { exocrine pancreas dysfunction }\end{array}$ & $\begin{array}{l}\text { Oral hypoglycemic } \\
\text { agents, insulin }\end{array}$ \\
\hline INS-MODY & MODY10 & 613370 & Progressive beta-cell dysfunction & $\begin{array}{l}\text { Oral hypoglycemic } \\
\text { agents, insulin }\end{array}$ \\
\hline
\end{tabular}

* Online Mendelian Inheritance in Man

betic subjects. This agrees well with an estimate of MODY in $2 \%$ of all diabetic subjects, made by Ledermann (27). Translating the HUNT2 finding to the whole country of Norway, with some 215000 subjects with diabetes (4.3\% in HUNT3), gives us approximately 4300 cases of clinical MODY.

Thus, it seems safe to estimate that in Norway we are dealing with a group of at least 2500-5000 persons who have MODY-type diabetes and that might benefit from a molecular diagnosis. As mentioned, only 458 persons have a molecularly confirmed MODY diagnosis so far.

In the MODY Registry, HNF1A-MODY is clearly the most prevalent type, accounting for $53 \%$ of families with a genetic diagnosis (Table 1). By comparison, the relative prevalence of GCK-MODY is $30 \%$. In Norway, GCK-MODY still appears to be less common than HNF1A-MODY, as we concluded in a previous study (9). However, true prevalence data of GCKMODY are difficult, or even impossible, to obtain without systematic screening in large groups of children.

Norwegian families with identical HNF1A mutations tend to stem from the same geographical area. Bjørkhaug et al. (5) determined haplotypes for recurrent mutations, and found that a founder effect was likely for the hot-spot mutation P291fsinsC and possibly also for $\mathrm{P} 112 \mathrm{~L}$ and $\mathrm{R} 131 \mathrm{~W}$. At least seven of the eleven R229Q-positive probands of the Norwegian MODY Registry originate from either Nord- or Sør-Trøndelag county (18). A founder effect is able to shape the local prevalence MODY. The lack of population-based data clearly prohibits a definite conclusion on the geographic distribution of MODY in Norway.

In our work we found, not unexpectedly, admixtures of type 2 diabetes in families with monogenic diabetes. This should be kept in mind during the delineation of MODY phenotypes, since MODY as such is characterized by neither obesity nor hyperlipidemia. Interestingly, we have found that common type 2 diabetes risk variants of modest effect sizes reduce the age at diagnosis in HNF1A-MODY (28). Thus, clinical characteristics of a monogenic disease can be modified by common polygenic variants.

Neonatal diabetes, now defined as diabetes before 6 months of age, is a rare condition (29). The distinction between transient and permanent neonatal diabetes is difficult because "transient" cases may have relapses, and "permanent" cases may show remissions. Longterm follow-up is necessary to make a distinction between transient and permanent neonatal diabetes (30). In many subtypes of neonatal diabetes and in some MODY subtypes, symptoms and signs other than diabetes may dominate the phenotype, eg. pancreatic aplasia, exocrine dysfunction, renal dysfunction or urogenital malformations $(2,13,31)$.

Of particular importance is that certain types of neonatal diabetes may be treated with oral sulfonylurea, periodically or permanently. Whereas the beneficial effect of sulfonylurea in neonatal diabetes was demonstrated many years ago (3), the good news is that patients may now be selected for such therapy on the basis of genetic testing, providing a nice example of pharmacogenetics $(22,23)$.

\section{CONCLUSION}

The Norwegian MODY Registry was established with the ultimate goal of improving diagnostics and treatment of monogenic diabetes. As shown by the examples discussed above, this registry has significantly increased our knowledge about the genetics of diabetes in Norway, and it will continue to serve scientific and diagnostic purposes in the years to come. We have registered more than 1500 suspected cases of monogenic diabetes and the number of patients who have received a genetic diagnosis is now approaching 500. In the future, we expect that more detailed phenotyping using radiological imaging and physiological characterization will improve the value of the registry, enabling us to diagnose monogenic diabetes more efficiently (32). An 
example is the use of ultrasound examination to diagnose HNF1B-MODY and CEL-MODY $(13,33)$. In the near future, we think tailored hybridization capture for selected genes of interest and very high-coverage sequencing of specific gene panels will replace the traditional Sanger sequencing. Most likely, exome and possibly whole-genome sequencing will be the future state-of-the-art in molecular diagnositics of MODY (34). Also, we think the use of future "omics" (35) will be a step forward and we plan to add biomarker investigations in serum to the DNA analysis.

\section{ACKNOWLEDGEMENTS}

We are grateful to members of the families studied, for cooperation. Thanks are also due to colleagues from all over Norway who referred patients and families for diagnostic and investigative purposes. We also acknowledge the cooperation of staff members Kine Alme, Christine Heiberg Andersen, Ingvild Bjørlykke, Louise Grevle, Elin Horntvedt, Yvonne Müller, Monika Ringdal, Benedikte Rosenlund, Marie Solheim and Liv Aasmul of the Norwegian Study Group of Childhood Diabetes. We thank the University of Bergen, Helse Vest, Innovest, Norwegian Research Council, KG Jebsen Foundation, Norwegian Diabetes Association, European Research Council (AdG) and Nordhordlands lag av Norges Diabetesforbund for funds and support.

\section{REFERENCES}

1. Molven A, Njølstad PR. Role of molecular genetics in transforming diagnosis of diabetes mellitus. Expert Rev Mol Diagn 2011; 11: 313-20.

2. Haldorsen IS, Ræder H, Vesterhus M, Molven A, Njølstad PR. The role of pancreatic imaging in monogenic diabetes mellitus. Nat Rev Endocrinol 2011; 8: 148-59.

3. Oseid S, Søvik O, Aagenæs Ø. Idiopathic Neonatal Hyperglycemia. $13^{\text {th }}$ International Congress on Pediatrics. Vienna: Congress Book, 1971; vol 7: 437-41.

4. Heiervang E, Følling I, Søvik O, Sandnes T, Myrmael T, Moen T, Myking O. Maturity-onset diabetes of the young: Studies in a Norwegian family. Acta Paediatr Scand 1989; 78: 74-80.

5. Bjørkhaug L, Sagen JV, Thorsby P, Søvik O, Molven A, Njølstad PR. Hepatocyte nuclear factor-1 alpha gene mutations and diabetes in Norway. J Clin Endocrinol Metab 2003; 88: 920-31.

6. Sagen JV, Njølstad PR, Søvik O. Reduced prevalence of late-diabetic complications in MODY3 with early diagnosis. Diabet Med 2002; 19: 697-8.

7. Holmen J, Midthjell K, Krüger $\varnothing$, Langhammer A, Holmen TL, Bratberg GH et al. The Nord-Trøndelag Health Study 1995-97 (HUNT2): objectives, contents, methods and participation. Norsk Epidemiologi 2003; 13: 19-32.

8. Sagen JV, Baumann ME, Salvesen HB, Molven A, Søvik O, Njølstad PR. Diagnostic screening of NEUROD1 (MODY6) in subjects with MODY or gestational diabetes mellitus. Diabet Med 2005; 22: 1012-5.

9. Sagen JV, Bjørkhaug L, Molnes J, Ræder H, Grevle L, Søvik O, Molven A, Njølstad PR. Diagnostic screening of MODY2/GCK mutations in the Norwegian MODY Registry. Pediatr Diabetes 2008; 9: 442-9.

10. Ræder H, Bjørkhaug L, Johansson S, Mangseth K, Sagen JV, Hunting A, Følling I, Johansen O, Bjørgaas M, Paus PN, Søvik O, Molven A, Njølstad PR. A hepatocyte nuclear factor-4 alpha gene (HNF4A) P2 promoter haplotype linked with late-onset diabetes: studies of HNF4A variants in the Norwegian MODY registry. Diabetes 2006; 55: 1899-903.

11. Lindner TH, Njølstad PR, Horikawa Y, Bostad L, Bell GI, Søvik O. A novel syndrome of diabetes mellitus, renal dysfunction and genital malformation associated with a partial deletion of the pseudo-POU domain of hepatocyte nuclear factor-1beta. Hum Mol Genet 1999; 8: 2001-8.

12. Sagen JV, Bostad L, Njølstad PR, Søvik O. Enlarged nephrons and severe nondiabetic nephropathy in hepatocyte nuclear factor-1beta (HNF-1beta) mutation carriers. Kidney Int 2003; 64: 793-800.

13. Haldorsen IS, Vesterhus M, Ræder H, Jensen DK, Søvik O, Molven A, Njølstad PR. Lack of pancreatic body and tail in HNF1B mutation carriers. Diabet Med 2008; 25: 782-7.

14. Ræder H, Johansson S, Holm PI, Haldorsen IS, Mas E, Sbarra V, Nermoen I, Eide SA, Grevle L, Bjørkhaug L, Sagen JV, Aksnes L, Søvik O, Lombardo D, Molven A, Njølstad PR. Mutations in the CEL VNTR cause a syndrome of diabetes and pancreatic exocrine dysfunction. Nat Genet 2006; 38: 54-62.

15. Torsvik J, Johansson S, Johansen A, Ek J, Minton J, Ræder H, Ellard S, Hattersley A, Pedersen O, Hansen T, Molven A, Njølstad PR. Mutations in the VNTR of the carboxyl-ester lipase gene (CEL) are a rare cause of monogenic diabetes. Hum Genet 2010; 127: 55-64.

16. Molven A, Ringdal M, Nordbø AM, Ræder H, Støy J, Lipkind GM, Steiner DF, Philipson LH, Bergmann I, Aarskog D, Undlien DE, Joner G, Søvik O; Norwegian Childhood Diabetes Study Group, Bell GI, Njølstad PR. Mutations in the insulin gene can cause MODY and autoantibody-negative type 1 diabetes. Diabetes 2008; 57: 1131-5.

17. Støy J, Edghill EL, Flanagan SE, Ye H, Paz VP, Pluzhnikov A, Below JE, Hayes MG, Cox NJ, Lipkind GM, Lipton RB, Greeley SA, Patch AM, Ellard S, Steiner DF, Hattersley AT, Philipson LH, Bell GI; Neonatal Diabetes International Collaborative Group. Insulin gene mutations as a cause of permanent neonatal diabetes. Proc Natl Acad Sci U S A 2007; 104: 15040-4. 
18. Eide SA, Ræder H, Johansson S, Midthjell K, Søvik O, Njølstad PR, Molven A. Prevalence of HNF1A (MODY3) mutations in a Norwegian population (the HUNT2 Study). Diabet Med 2008; 25: 775-81.

19. Njølstad PR, Søvik O, Cuesta-Muñoz A, Bjørkhaug L, Massa O, Barbetti F, Undlien DE, Shiota C, Magnuson MA, Molven A, Matschinsky FM, Bell GI. Neonatal diabetes mellitus due to complete glucokinase deficiency. N Engl J Med 2001; 344: 1588-92.

20. Njølstad PR, Sagen JV, Bjørkhaug L, Odili S, Shehadeh N, Bakry D, Sarici SU, Alpay F, Molnes J, Molven A, Søvik O, Matschinsky FM. Permanent neonatal diabetes caused by glucokinase deficiency: inborn error of the glucose-insulin signaling pathway. Diabetes 2003; 52: 2854-60.

21. Laborie LB, Mackay DJ, Temple IK, Molven A, Søvik O, Njølstad PR. DNA hypomethylation, transient neonatal diabetes, and prune belly sequence in one of two identical twins. Eur J Pediatr 2010; 169: 207-13.

22. Sagen JV, Ræder H, Hathout E, Shehadeh N, Gudmundsson K, Bævre H, Abuelo D, Phornphutkul C, Molnes J, Bell GI, Gloyn AL, Hattersley AT, Molven A, Søvik O, Njølstad PR. Permanent neonatal diabetes due to mutations in KCNJ11 encoding Kir6.2: patient characteristics and initial response to sulfonylurea therapy. Diabetes 2004; 53: 2713-8.

23. Pearson ER, Flechtner I, Njølstad PR, Malecki MT, Flanagan SE, Larkin B, Ashcroft FM, Klimes I, Codner E, Iotova V, Slingerland AS, Shield J, Robert JJ, Holst JJ, Clark PM, Ellard S, Søvik O, Polak M, Hattersley AT; Neonatal Diabetes International Collaborative Group. Switching from insulin to oral sulfonylureas in patients with diabetes due to Kir6.2 mutations. N Engl J Med 2006; 355: 467-77.

24. Babenko AP, Polak M, Cavé H, Busiah K, Czernichow P, Scharfmann R, Bryan J, Aguilar-Bryan L, Vaxillaire M, Froguel P. Activating mutations in the ABCC8 gene in neonatal diabetes mellitus. $N$ Engl $J$ Med 2006; 355: 456-66.

25. Shields BM, Hicks S, Shepherd MH, Colclough K, Hattersley AT, Ellard S. Maturity-onset diabetes of the young (MODY): how many cases are we missing? Diabetologia 2010; 53: 2504-8.

26. Kropff J, Selwood MP, McCarthy MI, Farmer AJ, Owen KR. Prevalence of monogenic diabetes in young adults: a community-based, cross-sectional study in Oxfordshire, UK. Diabetologia 2011; 54: 1261-3.

27. Ledermann HM. Is maturity onset diabetes at young age (MODY) more common in Europe than previously assumed? Lancet 1995; 345: 648.

28. Lango Allen H, Johansson S, Ellard S, Shields B, Hertel JK, Raeder H, Colclough K, Molven A, Frayling TM, Njølstad PR, Hattersley AT, Weedon MN. Polygenic risk variants for type 2 diabetes susceptibility modify age at diagnosis in monogenic HNF1A diabetes. Diabetes 2010; 59: 266-71.

29. Slingerland AS, Shields BM, Flanagan SE, Bruining GJ, Noordam K, Gach A, Mlynarski W, Malecki MT, Hattersley AT, Ellard S. Referral rates for diagnostic testing support an incidence of permanent neonatal diabetes in three European countries of at least 1 in 260,000 live births. Diabetologia 2009; 52: 1683-5.

30. Søvik O, Aagenaes O, Eide SÅ, Mackay D, Temple IK, Molven A, Njølstad PR. Familial occurrence of neonatal diabetes with duplications in chromosome 6q24: treatment with sulfonylurea and 40-yr follow-up. Pediatr Diabetes 2012; 13: 155-62.

31. Gonc EN, Ozturk BB, Haldorsen IS, Molnes J, Immervoll H, Raeder H, Molven A, Søvik O, Njølstad PR. HNF1B mutation in a Turkish child with renal and exocrine pancreas insufficiency, diabetes and liver disease. Pediatr Diabetes 2012; 13: e1-5.

32. Njølstad PR, Molven A. To test, or not to test: time for a MODY calculator? Diabetologia 2012; 55: $1231-4$.

33. Ræder H, Haldorsen IS, Ersland L, Grüner R, Taxt T, Søvik O, Molven A, Njølstad PR. Pancreatic lipomatosis is a structural marker in nondiabetic children with mutations in carboxyl-ester lipase. Diabetes 2007; 56: 444-9.

34. Johansson S, Irgens H, Chudasama KK, Molnes J, Aerts J, Roque FS, Jonassen I, Levy S, Lima K, Knappskog PM, Bell GI, Molven A, Njølstad PR. Exome sequencing and genetic testing for MODY. PLoS One 2012; 7: e38050.

35. Ræder H, Molven A, Njølstad PR. Skreddersydd medisin eller narsissomikk? Tidsskr Nor Lageforen 2012; 132: $1844-5$. 